\title{
The Internet of Things as a customer experience tool
}

\author{
LESZEK MAREK ${ }^{1}$ (D) https://orcid.org/0000-0003-1448-6446 \\ JAROSŁAW WOŹNICZKA2 (iD https://orcid.org/0000-0001-9208-4544 \\ Wroclaw University of Economics, Faculty of Economic Sciences, \\ Department of Marketing Management
}

\begin{abstract}
The Internet of Things (IoT) is a relatively new technological innovation, the use of which is now widely discussed in the scientific and business literature. This article undertakes the research problem of potential of the IoT as a tool supporting designing Customer Experience (CX). The development of the IoT along with its market potential was discussed, the definitions and terms related to customer experience were presented and the adoption of IoT in the field of CX was conceptualized. Then the significance of CX analysing and planning was underlined and the fields in which the IoT can support the customer experience management process were indicated. Finally, various empirical examples of the use of IoT serving as a tool for building positive customer experience with the brand were presented. The desk research method has been used, including literature review and the analysis of the results of empirical studies.
\end{abstract}

Paper type: review and conceptual article

Key words: Internet of Things, Customer Experience, touch points, smart objects, customer behaviour, customer experience management.

\section{Introduction}

Technological innovations, such as the Internet of Things (IoT), create new business and research opportunities and pose new challenges for managers and scientists. The system of communication between objects has contributed to the

\footnotetext{
1 leszek.marek@ue.wroc.pl

2 jaroslaw.wozniczka@ue.wroc.pl
} 
increase in the amount of information available to managers about their consumers (Frąckiewicz, 2016). According to Kwiatkowska (2014) the Internet is developing from a network of connected computers into a network of various devices like vehicles, smartphones, household appliances, toys etc., constantly connected, communicating with each other and exchanging information. This enables establishing a steady stream of data how a consumer uses specified products throughout their life cycles. In addition, the IoT brings a huge potential for innovation and allows marketers to create new ways of gaining competitive advantage. It also supports companies in the process of managing customer experience in the course of their relationship with a company, brand or a product, leading to the increase of a customer satisfaction and the companies' results.

The development and multiplicity of the devices connected to the Internet are the cause of the growing number of data generated and distributed by them. Consequently, they are also able to provide information about observed consumer experiences during the use or other contacts with a product. Thanks to the IoT technology the marketers gain access to a broad and uninterrupted stream of data, which in turn gives them insight into users behaviours, their interactions with products and a knowledge of how to communicate with them effectively (Patel, 2015; Porter \& Heppelmann, 2014). Moreover, it is claimed that IoT has a potential to revolutionize the customer experience. As customers can interact with smart objects and objects can work together as assemblages through a process of ongoing interaction, new qualities and capacities are going to emerge, expanding the range of mutual interactions beyond the human-centric paradigm (Hoffman \& Novak, 2018).

\section{The development of the Internet of Things}

In 1991, Weiser has used the term "ubiquitous computerization" for the first time, anticipating common computerization, manifested in the exploitation of IT technologies in a large number of devices applied in various areas of a professional and private life. The IoT technology was named shortly after, in 1999, by Ashton (2009), who used this term in a presentation prepared for the Procter \& Gamble company. He described the IoT as an ecosystem of devices equipped with sensors, communicating and exchanging data with each other. Ashton envisaged that these devices will be able to collect information on their own and that sensor technology will enable them to observe, identify and understand the world without restrictions due to the necessity of data input by humans. The devices described by him have been referred to as smart objects (Kortuem, Kawsar, Sundramoorthy, \& Fitton, 2010). Thus IoT is defined as a set of devices that are capable of network communication and of processing data transmitted and identified by the network itself (Działdowski, 2014). 
Among the essential areas of the IoT applications Vermesan and Friess (2014) list the fields like "smart cities," energy, transport, home, industry, health, logistics, industry, security and co-participation. Atzori, Iera, and Morabito (2014) group the IoT applications in five general domains: transport and logistics, health care, intelligent environment, personal and social applications and futuristic applications. Manyika et al. (2015) made a prediction of the market potential of the Internet of Things as for 2025. With regard to their research, the IoT will be represented by the following domains and values: office (150 billion $\$$ ), home (350 billion $\$$ ), vehicles (740 billion $\$$ ), logistics (850 billion $\$$ ), work site (930 billion $\$$ ), retail (1.2 billionT \$), man (1.6 billionT \$), city (1.7 billionT \$) and factories (3.7 T \$).

Atzori, Iera, and Morabito (2010) point out such capabilities of the IoT like autonomy and proactive behaviour, awareness of the environment, cooperation in the field of communication and data exchange. The importance of the ability of devices to communicate with each other, as well as with the operator, was highlighted in various publications (Manyika, et al., 2015; Atzori, et al., 2010; Porter \& Heppelmann, 2014). Porter and Heppelmann (2014) defined three basic dimensions of the Internet of Things: one-to-one communication, one-to-many communication, and many-to-many communication (see Figure 1).

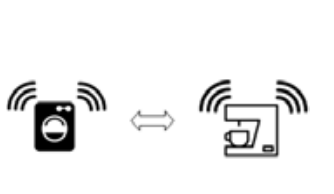

one-to-one

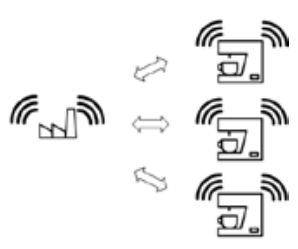

one-to-many

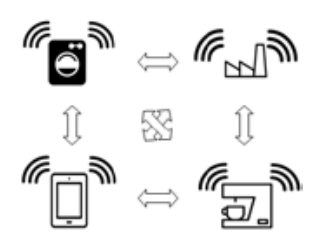

many -to-many

Figure 1. Three dimensions of the Internet of Things communication.

Source: own work based on Porter \& Heppelmann, 2014, pp. 5-6.

Smart objects communicating with each other can achieve such functionalities as monitoring, control, process optimization and autonomy. It is claimed that smart devices would be able to communicate anytime, anywhere and by any media (Atzori, et al., 2010). In addition, a jump in the technological development from 'smart' to 'socially aware' level is expected. According to the predictions the next generation of smart devices, called social objects, will be characterized by such functionalities as interaction with other objects in an autonomous way, the ability to search the Internet of Things (i.e. the network of billions of objects) in order to obtain relevant information and the ability to manifest its existence in order to provide services to the network (Atzori, et al., 2010). In the later article Atzori et al. (2014) stated that 
devices would become blog-jets, that is they will actively communicate with the environment. It means that their users will become an element of the ecosystem in which mutual interactions with intelligent devices will take place.

\section{Customer experience}

Twenty years ago Pine II and Gilmore (1998) noticed that many goods and services were losing their distinction and become more and more common to customers, so companies are forced to compete through providing them with special user experiences. This concept was developed by Meyer and Schwager (2007) and was referring to the customer experience defined as the internal and subjective response customers have to any direct or indirect contact with a company. According to them, the data about customer experiences are collected at so-called touch points, meaning all customer's direct contacts with the organization, brand or product. Customer experience is also described as a result of multiple interactions between a customer and a product or a company, always personal and of rational, emotional, sensorial, physical and even spiritual nature (Gentile, Spiller, \& Noci, 2007), or as a multidimensional construct involving the customer's cognitive, affective, behavioural, physical and social responses to a company's offerings during the customer's purchase journey (Verhoef, et al., 2009; Lemon \& Verhoef, 2016). Sudolska (2011) defines the customer experience as the total number of impressions created as a result of all customer interactions with a company through contacts with products, employees, service and self-service technologies, along with the accompanying information message. The process of developing the customer experience includes such phases like awareness, discovery, attraction, interaction, purchase, use, cultivation and advocacy (Atkinson, 2016). The final result of customer experience is what customers think and feel about a company or a brand and how strong is the bond between them (Sirapracha \& Tocquer, 2012).

Wereda and Grzybowska (2016) point out that the measurement of the customer experience requires a comparison between the individual's experience resulted from all touch points with a product, brand or company and his or her expectations towards them. They also define customer experience management as "a science about knowing your customers as completely as possible." This knowledge enables an organization to provide customized experiences to customers, making them not only loyals, but also the advocates.

It is emphasized that a comprehensive knowledge about customers is essential for creating relationships with them, and the analysis of data collected in companies databases can serve as the basis for anticipation of future customer behaviours and needs (Sudolska, 2011). Porter and Heppelmann (2014) accentuate the importance of in-depth insights into the value provided to customers by products. A deep 
knowledge about customers comes from data recorded at all touch points between a customer and the organization. Customer experience management involves processing of collected information in a fast and effective manner with due diligence (Wereda \& Grzybowska, 2016).

The results of the research conducted by McKinsey \& Company stress the importance of a customer decision journey, i.e. the chronological approach to interactions created at touch points in the customer experience management process (Court, Elzinga, Mulder, \& Vetvik, 2009; Duncan, Fanderi, Maechler, \& Neher, 2016). The concept of mapping interactions with the help of the tool known as Customer Journey Map was introduced by the IDEO company and used for the first time in 1999 in the project of designing services for high-speed railways Acela (Brown, 2009). Other tools developed for the purpose of identification and analysis of customer experience include Service Experience Clues (Berry, Wall, \& Carbone, 2006), Servicescapes (Bitner, 1992) and Service Transaction Analysis (Johnston, 1999).

Brand loyalty is not only a result of the quality of products or its features, but it is a resultant of the sum of experiences gathered in course of customer interactions with the company or brand that can strengthen or weaken the relationship between them. Successful companies develop a strong emotional bond with customers, which translates into an increase in their loyalty and their propensity to recommend the brand. According to the results of the research conducted by IBM (2015), an effective Customer Experience Management must be a non-unitary project, but a comprehensive business philosophy.

\section{The Internet of Things as a tool for improving the customer experience}

The IoT can be perceived as developed deliberately for designing and managing the customer experience. Smart devices can automatically, by means of sensors, collect and transfer data obtained at numerous touch points. Their later analysis can be used to increase the number of positive interactions between customers and a product, a brand or a company, and to eliminate interactions negatively evaluated by customers. They can also provide an interface supporting the satisfaction survey, e.g. evaluation of the service in the store. IoT can also be used to build relationships and emotional ties with customers, deliver products that meet their expectations at a utilitarian level, improve product service and reinvent marketing communications.

In 2009 the number of devices connected to the Internet was for the first time higher than the number of inhabitants of the globe (6.5 billion). In 2017 this number exceeded 12.5 billion, and it is estimated that the number of smart devices connected to the Internet will reach 30 billion by 2020 , and by $2025-75$ billion (Evans, 2014; Statista, 2018). This trend creates an unprecedented opportunity to 
build competitive advantage by supporting customer experience management and enriching organization's knowledge about customers through the precise identification of touch points and mapping a customer journey from the first contact with a brand, through product purchase, up to its use throughout the entire life cycle. Smart devices enable registration of every single interaction with a customer and an automatic transfer of these data between them. Tracking subsequent interactions and their analysis allows for a thorough analysis of how products are used by customers during their life cycle, as well as an accurate recognition of the needs and values that guide consumers.

Data obtained from sensors of various devices, their analysis and finally insights into customer behaviour ensure the ability to adapt products to customer needs, thus enabling the design of interactions maximizing delivery of positive experiences. The IoT allows you to obtain immediate and instant feedback which further improves business decision-making processes and a product design (Das, 2016).

It is widely believed that the use of Internet of Things increases capabilities of delivering a superior customer experience and that IoT has the potential to create new and innovative ways to understand and influence customer behaviour (Kocher, 2017; Martin, 2017; Raftery, 2017; Rossi, 2017). The selected opportunities for improving customer experience by implementation of the Internet of Things technology are presented in Table 1.

Global brands, such as Amazon, Nike, Sephora and Tesla have already included the Internet of Things into their marketing strategies. As a result, these companies have introduced products and services supported by the mutual communication devices, using them as tools for creating a unique customer experience, developing emotional ties with customers and building the competitive advantage.

\section{Table 1 Internet of Things and its impact on customer experience}

\begin{tabular}{|l|l|}
\hline \multicolumn{1}{|c|}{ IoT opportunities } & \multicolumn{1}{c|}{ Description } \\
\hline $\begin{array}{l}\text { IoT increases and improves } \\
\text { the flow of data about cus- } \\
\text { tomers' behaviours }\end{array}$ & $\begin{array}{l}\text { Collecting and analysing data provided by smart devices gives a rich } \\
\text { insight into customers' purchasing and using behaviours and habits }\end{array}$ \\
\hline $\begin{array}{l}\text { IoT enables uncovering } \\
\text { customer's behaviour in its } \\
\text { natural context }\end{array}$ & $\begin{array}{l}\text { Getting real-time data from smart devices allows continuous tracking } \\
\text { of customers' activities in various locations and identifying their touch } \\
\text { points with products in a customer journey }\end{array}$ \\
\hline $\begin{array}{l}\text { IoT allows offering high } \\
\text { performing products }\end{array}$ & $\begin{array}{l}\text { Gathering and analysing data provided by IoT enables monitoring } \\
\text { products' performance and updating them on what increases the } \\
\text { customer satisfaction and readiness to continue the relationship with } \\
\text { a company }\end{array}$ \\
\hline $\begin{array}{l}\text { IoT enables building strong } \\
\text { relationships with custom- } \\
\text { ers by providing them with } \\
\text { special services }\end{array}$ & $\begin{array}{l}\text { Smart devices are used to deliver specially crafted services to the cus- } \\
\text { tomers, aimed to strengthen the bonds between customer and a brand } \\
\text { or a company }\end{array}$ \\
\hline
\end{tabular}




\begin{tabular}{|l|l|}
\hline $\begin{array}{l}\text { IoT enables keeping custom- } \\
\text { ers updated }\end{array}$ & $\begin{array}{l}\text { Sending customers updated information about the status of product } \\
\text { delivery to their smart devices has the positive effect on the wait- } \\
\text { ing time perception and reduces the number of inbound queries and } \\
\text { complaints }\end{array}$ \\
\hline $\begin{array}{l}\text { IoT helps improving service } \\
\text { processes }\end{array}$ & $\begin{array}{l}\text { Data obtained from wearable smart devices like watches, glasses or } \\
\text { wristbands can be used to improve queue management by shortening } \\
\text { waiting time at crowded places - stores, airports, amusement parks etc. }\end{array}$ \\
\hline $\begin{array}{l}\text { IoT enables predicting } \\
\text { product failures and offer- } \\
\text { ing improved maintenance } \\
\text { contracts }\end{array}$ & $\begin{array}{l}\text { The predictive failure models created upon the analysis of the IoT } \\
\text { data are used to detect failures before they occur and to provide better } \\
\text { maintenance contracts improving customers' experience and increas- } \\
\text { ing their lifetime value }\end{array}$ \\
\hline $\begin{array}{l}\text { IoT allows increasing the } \\
\text { level of personal service }\end{array}$ & $\begin{array}{l}\text { Collecting and analysing data from smart devices enables identifying } \\
\text { and predicting customers' needs, wants and preferences and helps to } \\
\text { respond to them in a meaningful and personalized way }\end{array}$ \\
\hline $\begin{array}{l}\text { IoT increases the accuracy of } \\
\text { advertising and sales promo- } \\
\text { tions }\end{array}$ & $\begin{array}{l}\text { Data provided by smart devices allows to substitute the standardized } \\
\text { advertising messages with the information adjusted to the customer's } \\
\text { needs and wants and to implement the improved programmes of sales } \\
\text { incentives rewarding customers for the frequency of product usage, } \\
\text { brand loyalty, etc. }\end{array}$ \\
\hline
\end{tabular}

In order to develop a strong and emotional relationship with customers, brands engage them in various activities. An example of such approach is the Nike+ concept (Natanson, 2016). Using the mobile application, Nike offers its customers a possibility to measure their training progress. Nike+ focuses on creating a community where users can invite each other to a group of friends, compare results and motivate each other for further training. A similar solution is the Sephora Visual Artist, an interactive application supported by the IoT and Augmented Reality technologies. It allows scanning of the user's face, analysing its parameters like the shape of lips or eyes colour, choosing the right products for make-up and trying them visually (Sanchez, 2017). The users can publish photos and stylizations in social media, and the selected cosmetics can be bought directly through the application. Contact with such services establishes one of the touch points between the brand and the customer. By encouraging users to interact, providing value or responding to the users' needs or aspirations, these products create the positive customer experience.

Bhattacharjee, Moreno, and Ortega (2016) suggest the strong relationship between positive customer experience and a commercial success of companies, claiming that emotionally engaged customers are three times more likely to recommend the product and to re-purchase it. This emotional commitment can be built by increasing the convenience of purchase with IT tools such as Oak Fitting Room. It is a device equipped with sensors that identify products brought to a fitting room and, when combined with a virtual user profile, displays them on an interactive monitor. In order to generate as many positive experiences as possible during the time spent in a fitting room, the device also enables adjustment of a light level and calling the 
staff. This solution has been introduced in the prestigious Ralph Lauren boutiques, creating a unique service quality at the point of purchase (Townsend, 2017).

The vision published by Amazon.com reads: "We strive to offer our customers the lowest possible prices, the best available selection, and the utmost convenience" (Amazon, 2018). It clearly indicates that the area of customer experience is in the centre of the company's attention. The company incorporated the Internet of Things concept, what resulted in the creation of innovative products aimed at increasing the convenience of purchase. The Amazon Dash device enables quick ordering of regularly purchased products directly from the Amazon.com website, thus fulfilling the requirement to increase the purchase convenience. The company has also opened the Amazon Go store, equipped with a set of sensors, advanced computer analytics and cameras, where customers can simply take products from the shelves and leave with no paying for them at the cash register point. The payment process takes place automatically through the customer's account on Amazon.com (Millman, 2016). The solutions cited above limit or virtually completely eliminate inconveniences associated with the purchasing process, thereby increasing the number of positive brand interactions as part of the purchase process.

The electric car Tesla Model $S$ is an example of a vehicle which thanks to the constant connection to the Internet enables an automatic transfer of data about its general condition and the condition of individual components to the manufacturer. These data are used to correct the installed software and to update it automatically. It is also possible to make minor car repairs without having to visit the service (Brisbourne, 2014). In the automotive industry, the service is crucial for creating interactions between the brand and the consumer. With the help of the IoT, car manufacturers can increase the level of user satisfaction. In the survey regarding the purchased car satisfaction, carried out in 2017 by Consumer Reports (2017), the Tesla brand came in the first place with the result of $91 \%$ car owners claimed to be satisfied.

The use of the IoT is going to result in a greater availability of products optimized for individual requirements. The product responding to the needs of a specific target group, especially if it reflects the values shared by its members, will generate their positive experiences. Values mentioned above may include co-sharing, convenience or innovation. The solutions created with the help of the IoT, such as Autolib, Zipcar or CityBee, are good examples of satisfying needs of the customers who don't care for having an own vehicle but value co-sharing (Porter \& Heppelmann, 2014). The traditional model of product ownership is more and more often replaced by the as-a-service model, especially in the case of organizational customers. In this model, the supplier provides a service for a customer who pays only for the time of the actual use of the device and the contracted effectiveness level (Gubbi, Buyya, Marusic, \& Palaniswami, 2013).

The maintenance, service and repairs are also a very important field of building customer experience on B2B markets. The Cat ${ }^{\oplus}$ Asset Intelligence platform 
developed by the Caterpillar company is an example of the solution supporting the provision of proper service to customers. The application monitors sensor data indicating the status of devices and allows operators to adjust their parameters, e.g. generator output power. When any problem occurs, the Caterpillar service centres analyse this automatic notification in order to provide the customer with a quick and optimal solution. This solution speeds up the repair time by shortening the interaction path and unblocking the malfunctioned equipment, what affects the level of customer satisfaction with the product and its servicing (Marr, 2017). Digitalization of interaction paths as such can be a method for building positive customer experience. The activities of this kind include providing customers with applications for tracking orders in real time or delivering information on the status of devices, planned technical inspections or a machine wear (Maechler, Sahni, \& Oostrum, 2016).

The IoT is also changing traditional marketing communications. Mittal (2012) notes that shopping centres, sales networks, public utilities and outdoor advertising providers have adapted the IoT technology to deliver personalized information, customized advertising messages and sales promotions offers to their customers. The consumers will soon receive only the filtered message content adjusted to their needs and interests, delivered both by traditional communication channels and smart devices themselves, e.g. a smart fridge. Unwanted advertising messages, which may have a negative impact on the customer experience, are going to be eliminated.

Therefore the IoT enables companies to limit potentially negative experiences resulting from receiving standardized marketing messages. The ability of direct communication with users of numerous smart devices opens up a potential for monitoring their behaviour, analysing it, as well as proactively keeping the organizations towards providing customers with positive experiences. It gives them an almost unlimited opportunity to listen to customers' needs and provide them with the right answer, at the right time and through the right channels.

While stressing the value of the Internet of Things as a tool offering a potential for significant increase of customer satisfaction through generating positive consumer experience, everyone must be aware of the security threats and challenges for individual privacy protection. In a growing number of publications the issue of risk emerging from smart objects collecting enormous amount of private data, often of vulnerable nature, and the need for their effective protection are underlined (Alaba, Othman, Hashem, \& Alotaibi, 2017; Conti, Dehghantanha, Franke, \& Watson, 2018; Lopez, Rios, Bao, \& Wang, 2017; Peppet, 2014; Weber, 2015; Weinberg, Milne, Andonova \& Hajjat, 2015; Ziegeldorf, Morchon, \& Wehrle, 2014). The trade-off between customer benefits resulting from the IoT and the privacy protection has to be reached. The inevitable process of gathering and processing personal data with help of marketing analytics, business intelligence and machine learning systems is already to some extent regulated but there's still much work to be done. 
Like in case of any big data processing all individual data should be protected by effective technical solutions and the scope of data collected by IoT systems, the accessibility to data and the purposes for which the data is used should be limited by strict legal and ethical regulations. The challenges for data security in IoT systems and conventional networks are considered to be similar, but the ways of handling security issues in IoT differ and require applying advanced technology (Alaba, et al., 2017).

\section{Conclusions}

The IoT is a tool used more and more often in the area of customer experience management, aiming to increase customers' satisfaction, loyalty and trust. Knowledge of what constitutes value for a customer is the basis for forming a lasting relationship with him or her, and as a result, translates into building a competitive advantage for the company. The most recognizable fashion, retailing, automotive or industrial brands focus on creating positive customer experiences at multiple touch points. When using the IoT every customer contact with a smart object becomes digital, what creates an opportunity for a company to get new and rich knowledge of the customer behaviour and to act proactively towards providing the perfect customer experience in the future. The Internet of Things facilitates gathering and analysing information about customer's habits and preferences, allowing for more precise mapping of interactions between a brand and a consumer and anticipating his or her future purchase decisions.

The areas of a successful implementation of the IoT as a tool facilitating the process of customer experience management include consumer research, product and service designing, maintaining and repair, personal service, marketing communications and relationship management. The continuous development of the IoT is not only going to open hitherto unknown opportunities for marketing and customer experience design but also to change the traditional perception of human-object relationships.

\section{References}

Alaba, F.A., Othman, M., Hashem, I.A.T., \& Alotaibi, F. (2017). Internet of things security: A survey. Journal of Network and Computer Applications, 88, 10-28.

Amazon (2018). Retrieved from https://www.amazon.jobs/en-gb/business_categories/retail [accessed: 4.05.2018].

Ashton, K. (2009). That 'Internet of Things' thing. Retrieved from www.rfidjournal.com [accessed: 03.05.2017]. 
Atkinson, R. (2016). Focus on customer experience: Combining people and technology to deliver for customers. Retrieved from https://www.thinkhdi.com/library/supportworld/2016 [accessed: 4.05.2018].

Atzori, L., Iera, A., \& Morabito, G. (2010). The Internet of Things: A survey. Computer Networks, 54(15), 2787-2805.

Atzori, L., Iera, A., \& Morabito, G. (2014). From "smart objects" to "social objects": The next evolutionary step of the Internet of Things. IEEE Communications Magazine, 52(1), 97-104.

Berry, L.L., Wall, A.E., \& Carbone, L.P. (2006). Service clues and customer assessment of the service experience: Lessons from marketing. Academy of Management Perspectives, 20(2), 43-57.

Bhattacharjee, D., Moreno, J., \& Ortega, F. (2016). The secret to delighting customers: Putting employees first. McKinsey Quaterly, (3), 40-47.

Bitner, M.J. (1992). Servicescapes: The impact of physical surroundings on customer and employees. Journal of Marketing, 56(2), 57-71.

Brisbourne, A. (2014). Tesla's over-the-air fix: Best example yet of the Internet of Things? Wired Magazine. Retrieved from: https://www.wired.com [accessed: 08.09.2017].

Brown, T. (2009). Change by Design. How Design Thinking Transforms Organizations and Inspires Innovation. New York: HarperCollins.

Consumer Reports (2017). Car brands ranked by owner satisfaction. Retrieved from: https:// www.consumerreports.org/ [accessed: 6.05.2018].

Conti, M., Dehghantanha, A., Franke, K., \& Watson, S. (2018). Internet of Things security and forensics: Challenges and opportunities. Future Generation Computer Systems, 78, 544-546.

Court, D., Elzinga, D., Mulder, S., \& Vetvik, O.J. (2009). The consumer decision journey. McKinsey Quarterly, (1), 1-11.

Das, D. (2016). Offer wonderful customer experience with Internet of Things. Retrieved from: www.kelltontech.com [accessed: 01.01.2018].

Duncan, E., Fanderi, H., Maechler, N., \& Neher, K. (2016). Customer experience: Creating value through transforming customer journeys. McKinsey \& Company, (1), 3-7.

Działdowski, A. (2014). Internet of Things - wyzwania dla bezpieczeństwa. Retrieved from: https://www.pcworld.pl397637.html [accessed: 2.04.2018].

Evans, D. (2014). The Internet of Things how the next evolution of the Internet is changing everything. Retrieved from: https://www.cisco.com [accessed: 20.07.2018].

Frąckiewicz, E. (2016). Internet rzeczy - nowe oblicze komunikacji marketingowej? Zeszyty Naukowe WSB w Poznaniu, 67(2), 143-151.

Gentile, C., Spiller, N., \& Noci, G. (2007). How to sustain the Customer Experience: An overview of experience components that co-create value with the customer. European Management Journal, 25(5), 395-410.

Gubbi, J., Buyya, R., Marusic, S., \& Palaniswami, M. (2013). Internet of Things: A vision, architectural elements, and future directions. Future Generation Computer Systems, 29(7), 1645-1660.

Hoffman, D.L., \& Novak, T.P. (2018). Consumer and object experience in the Internet of Things: An assemblage theory approach, Journal of Consumer Research, 44(6), 1178-1204.

IBM (2015). 20:20 Customer Experience. Forget CRM - long live the customer! IBM customer experience study. Retrieved from: https://www-935.ibm.com/services/de/bcs/pdf/2006 [accessed: 12.03.2018].

Johnston, R. (1999). Service transaction analysis: Assessing and improving the customer's experience. Managing Service Quality, 9(2), 102-109. 
Kocher, D. (2017). Customer Experience and the Internet of Things. Retrieved from: https:// www.ge.com/digital/blog [accessed: 22.04.2018].

Kortuem, G., Kawsar, F., Sundramoorthy, V., \& Fitton, D. (2010). Smart objects as building blocks for the Internet of Things. IEEE Internet Computing, 14(1), 30-37.

Kwiatkowska, E.M. (2014). Rozwój Internetu rzeczy - szanse i zagrożenia. Internetowy Kwartalnik Antymonopolowy i Regulacyjny, 8(3), 60-70.

Lemon, K.N., \& Verhoef, P.C. (2016). Understanding customer experience throughout the customer journey. Journal of Marketing, 80(6), 69-96.

Lopez, J., Rios, R., Bao, F., \& Wang, G. (2017). Evolving privacy: From sensors to the Internet of Things. Future Generation Computer Systems, 75, 46-57.

Maechler, N., Neher, K., \& Park, R. (2016). From touchpoints to journeys: Seeing the world as customers do. Retrieved from: https://www.mckinsey.com/business-functions/marketingand-sales/our-insights [accessed: 4.05.2018].

Maechler, N., Sahni, S., \& Oostrum, M. (2016). Improving the business-to-business customer experience. Retrieved from: https://www.mckinsey.com/business-functions/marketingand-sales/our-insights [accessed: 4.05.2018].

Manyika, J., Chui, M., Bisson, P., Woetzel, J., Dobbs, R., Bughin, J., \& Aharon, D. (2015). The Internet of Things: Mapping the value beyond the hype. Retrieved from: https://www. mckinsey.de [accessed: 17.08.2017].

Marr, B. (2017). IoT and Big Data at Caterpillar: How predictive maintenance saves millions of dollars. Retrieved from: https://www.forbes.com [accessed: 03.09.2017].

Martin, M. (2017). How the IoT Is Changing the customer experience and improving competitive advantage. Retrieved from: http://www.rfidjournal.com/articles/ view?16790 [accessed: 22.04.2018].

Meyer, Ch., \& Schwager, A. (2007). Understanding customer experience. Harvard Business Review, 85(2), 116-126.

Millman, R. (2016). Amazon go looks to IoT to eliminate queues at the checkout. Retrieved from: https://internetofbusiness.com [accessed: 24.06.2017].

Mittal, S. (2012). 25 retailers nailing it with their proximity marketing campaigns. Retrieved from: https://blog.beaconstac.com [accessed: 20.11.2017].

Natanson, E. (2016). Best practices: How to use apps drive loyalty and revenue. Retrieved from: http://adage.com [accessed: 18.08.2017].

Patel, N. (2015). How the Internet of Things is changing online marketing. Retrieved from: https://www.forbes.com [accessed: 09.09.2017].

Peppet, S.R. (2014). Regulating the Internet of Things: First steps toward managing discrimination, privacy, security and consent. Texas Law Review, 93(1), 85-178.

Pine II, J.B., \& Gilmore, J.H. (1998). Welcome to the experience economy. Harvard Business Review, 76(4), 97-105.

Porter, M.E., \& Heppelmann, J.E. (2014). How smart, connected products are transforming competition. Harvard Business Review, 92(11), 64-88.

Raftery, T. (2017). How to enrich the customer experience using Internet of Things. Retrieved from: https://www.forbes.com/sites/sap/2017/12/21/\#5002e0065bb0 [accessed: 22.04.2018].

Rossi, B. (2017). How to improve customer experience with the Internet of Things. Retrieved from: http://www.information-age.com/123467559 [accessed: 22.04.2018].

Sanchez, C. (2017). Sephora virtual artist debuts new cheek product try on, expanded looks and ai-powered color match in latest update. Retrieved from: https://www.multivu.com [accessed: 08.08.2017]. 
Sirapracha, J., \& Tocquer, G. (2012). Customer experience, brand image and customer loyalty in telecommunication services, International Conference on Economics, Business and Marketing Management IPEDR, 29, 112-117.

Statista (2018). Internet of Things connected devices installed base worldwide from 2015 to 2025 (in billions). Retrieved from: https://www.statista.com/statistics/471264 [accessed: 6.05.2018].

Sudolska, A. (2011). Zarządzanie doświadczeniami klientów jako kluczowy czynnik w procesie budowania ich lojalności, Zeszyty Naukowe Uniwersytetu Szczecińskiego, 660, 275-286.

Townsend, M. (2017). "Smart mirrors" come to the fitting room. Retrieved from: www.bloomberg.com [accessed: 11.09.2017].

Verhoef, P.C., Lemon, K.N., Parasuraman, A., Roggeveen, A., Tsiros, M., \& Schlesinger, L.A. (2009). Customer experience creation: Determinants, dynamics and management strategies. Journal of Retailing, 85(1), 31-41.

Vermesan, O., Friess, P.I., et al. (2014). Internet of Things. Strategic research and innovation agenda. In O. Vermesan, P. Friess (eds.), Internet of Things. From Research and Innovation to Market Deployment. Retrieved from: http://www.internet-of-things-research.eu/pdf [accessed: 14.04.2018].

Weber, R.H. (2015). Internet of things: Privacy issues revisited. Computer Law \& Security Review, 31(5), 618-627.

Weinberg, B.D., Milne, G.R., Andonova, J.G., \& Hajjat, F.M. (2015). Internet of Things: Convenience vs. privacy and secrecy. Business Horizons, 58(6), 615-624.

Weiser, M.D. (1991). The computer for the $21^{\text {st }}$ century, Scientific American, 265(9), 94-104.

Wereda, W., \& Grzybowska, M. (2016). Customer Experience - does it matter? Modern Management Review, 23(3), 199-207.

Ziegeldorf, J. H., Morchon, O.G., \& Wehrle, K. (2014). Privacy in the Internet of Things: threats and challenges. Security and Communication Networks, 7(12), 2728-2742.

\section{Notes about the Authors}

LeSZeK MAREK - is a doctoral student at Wroclaw University of Economics. He has a Master's degree in Marketing and Management and is also academic teacher at the University of Lower Silesia. He has many years of work experience in marketing communication and B2B marketing. Recently he wrote about marketing utilization of the Internet of Things.

JARosŁaW WoźniCzKA - is an associate professor and the head of the Department of Marketing Management at the Faculty of Economic Sciences at Wroclaw University of Economics. He's the author and co-author of monographs, handbooks and scientific papers in the field of marketing and marketing management. He specializes in marketing communications, advertising management and research, marketing ethics and social and economic effects of marketing. Recently he also wrote about big data and marketing analytics. 
